\title{
PENGARUH HASIL BELAJAR PEMASARAN ONLINE DAN HASIL BELAJAR KEWIRAUSAHAAN TERHADAP KINERJA PENJUALAN ONLINE PESERTA DIDIK SMK NEGERI SURABAYA
}

\author{
Hari Effendi, SMK Negeri 10 Surabaya \\ effendihari@yahoo.co.id
}

\begin{abstract}
ABSTRAK
Penelitian ini bertujuan untuk menganalisa ada tidaknya pengaruh hasil belajar pemasaran online terhadap kinerja penjualan online, menganalisa ada tidaknya pengaruh hasil belajar kewirausahaan terhadap kinerja penjualan online dan menganalisa ada tidaknya pengaruh hasil belajar pemasaran online dan kewirausahaan secara simultan terhadap kinerja penjualan online yang diterapkan pada peserta didik kelas 10 SMK Negeri Bidang keahlian Manajemen Bisnis, Paket keahlian Pemasaran di Kota Surabaya. Penelitian ini dilaksanakan pada semester genap 2014 - 2015 dengan pendekatan kuantitatif ini, pada peserta didik SMK negeri Surabaya, yaitu SMK negeri 10, SMK Negeri 4 dan SMK Negeri 1 Surabaya dengan sampel sebanyak 135 peserta didik. Berdasarkan hasil analisis data, dapat disimpulkan bahwa ada pengaruh signifikan hasil belajar pemasaran online terhadap kinerja penjualan online, ada pengaruh signifikan hasil belajar kewirausahaan terhadap kinerja penjualan online, ada pengaruh signifikan secara bersama - sama hasil belajar pemasaran online dan hasil belajar kewirausahaan terhadap kinerja penjualan online.
\end{abstract}

Kata Kunci: Pemasaran Online, Kewirausahaan, Kinerja Penjualan Online

\section{ABSTRACT}

This study aimed to analyze whether there is influence learning outcomes online marketing on the performance of online sales, to analyze whether there is influence learning outcomes of entrepreneurship on the performance of online sales and analyze whether there is influence learning outcomes online marketing and entrepreneurship simultaneously on the performance of online sales is applied to learners class 10 SMK Field of expertise Business Management, Marketing Package expertise in Surabaya. The research was conducted in the second semester of 2014 2015 with this quantitative approach, the students SMK Surabaya, namely SMK 10, SMK Negeri 4 and SMK Negeri 1 Surabaya with a sample of 135 learners. Based on the results of data analysis, it can be concluded that there is a significant influence on the results of online marketing learning online sales performance, there is a significant effect on the performance of entrepreneurial learning outcomes online sales, there is a significant effect simultaneously learning outcomes online marketing and entrepreneurship learning outcomes for online sales performance.

Keywords: Online Marketing, Entrepreneurship, Online Sales Performance 


\section{PENDAHULUAN}

Salah satu pendidikan menengah berbentuk sekolah menengah atas adalah sekolah menengah kejuruan (SMK) atau bentuk lain yang sederajat. (UU Sisdiknas No 20 Tahun 2003: Pasal 18). Setiap tahunnya lulusan peserta didik SMK selalu dihadapkan pada 3 pilihan utama yaitu melanjutkan kejenjang pendidikan yang lebih tinggi (Perguruan tinggi), bekerja dan khusus untuk siswi terkadang dihadapkan dengan jenjang pernikahan.

Di Surabaya terdapat 11 Sekolah menengah Kejuruan, 3 diantaranya merupakan sekolah menengah kejuruan yang berbasis bidang keahlian bisnis manajemen yaitu : SMK Negeri 1 Surabaya, SMK Negeri 4 Surabaya dan SMK Negeri 10 Surabaya. (Dinas Pendidikan Kota Surabaya, 2015).

Salah satu bidang studi keahlian bisnis manajemen adalah program studi keahlian pemasaran. Salah satu tujuan dari program studi keahlian pemasaran adalah membawa peserta didik kearah yang lebih kreatif dan inovatif serta mempunyai daya juang pada bisnis penjualan produk yang dapat diandalkan. Hal ini dapat dilihat pada bagian struktur kurikulum terdapat sub bagian yaitu C2. Dasar Kompetensi Kejuruan Pemasaran : Pemasaran On-Line serta pada sub bagian yang lain yaitu Kelompok B (Wajib) : Prakarya dan Kewirausahaan (Permendikbud No 70 Tahun 2013: Tabel 10 )

Hal ini juga didukung dengan permendikbud Nomor 70 tahun 2013 yang menyatakan bahwa tujuan kurikulum 2013 yaitu untuk mempersiapkan manusia Indonesia agar memiliki kemampuan hidup sebagai pribadi dan warga negara yang beriman, produktif, kreatif, inovatif, dan afektif serta mampu berkontribusi pada kehidupan bermasyarakat, berbangsa, bernegara, dan peradaban dunia.

Berdasarkan hasil observasi di SMK Negeri 1, 4 dan 10 Surabaya pada kelas 10 PMSR peserta didik SMK sudah dibekali dengan pengetahuan dan keterampilan serta kinerja sesuai dengan kompetensi dan keahliannya masing - masing hal ini dapat dilihat pada pencapaian hasil belajar mata pelajaran Pemasaran online dan Kewirausahaan pada Kriteria Ketuntasan Minimal (KKM) diatas 75 disebutkan sebagai berikut :

Tabel 1. Pencapaian Hasil Belajar Pemasaran Online dan Kewirausahaan Peserta didik kelas 10 PMSR

\begin{tabular}{|c|c|c|c|}
\hline NO & SEKOLAH & \multicolumn{2}{|c|}{ Nilai Ulangan Harian $>75 ;$} \\
\hline & & Pemasaran Online & Kewirausahaan \\
\hline 1 & SMKN 1 Surabaya & $100 \%$ & $100 \%$ \\
\hline 2 & SMKN 4 Surabaya & $100 \%$ & $100 \%$ \\
\hline 3 & SMKN 10 Surabaya & $99 \%$ & $100 \%$ \\
\hline
\end{tabular}

Dalam tabel 1. terlihat bahwa peserta didik hampir semuanya mencapai hasil belajar nilai ulangan harian diatas KKM, hal ini bisa terjadi karena mata pelajaran pemasaran online dan kewirausahaan sangat mudah untuk dipelajari dan dipahami oleh peserta didik sehingga peserta didik mampu mencapai nilai yang maksimal. Tetapi pada kenyataannya masih banyak peserta didik yang belum menerapkan pengetahuan dan keterampilannya tersebut pada kondisi riil 
dilapangan. Salah satunya adalah melakukan penjualan produk secara online. Dan dari pengamatan peneliti terhadap peserta didik yang melalukan penjualan secara online hanya sedikit atau kurang dari $5 \%$, seperti pada tabel berikut :

Tabel 2. Tabel Peserta didik 10 PMSR yang melakukan penjualan online

\begin{tabular}{|c|c|c|}
\hline NO & SEKOLAH & $\begin{array}{c}\text { Peserta didik yang } \\
\text { melakukan penjualan online }\end{array}$ \\
\hline 1 & SMKN 1 Surabaya & 1 peserta didik \\
\hline 2 & SMKN 4 Surabaya & 1 peserta didik \\
\hline 3 & SMKN 10 Surabaya & 2 peserta didik \\
\hline
\end{tabular}

Menurut observasi dan pengamatan yang peneliti lakukan pada sekolah SMK Negeri 1, 4 dan 10 Surabaya pada kelas 10 PMSR sebenarnya peserta didik mampu untuk melakukan penjualan online karena mereka mempunyai pengetahuan dan keterampilan untuk melakukan penjualan online, hal ini bisa dilihat pada tabel berikut :

Tabel 3. Tabel Kemampuan Penggunaan Internet peserta didik kelas 10 PMSR

\begin{tabular}{|c|l|c|c|}
\hline NO & \multicolumn{1}{|c|}{ SEKOLAH } & $\begin{array}{c}\text { PENGGUNA } \\
\text { MEDIA SOSIAL }\end{array}$ & $\begin{array}{c}\text { PENGGUNA } \\
\text { BLOG }\end{array}$ \\
\hline 1 & SMKN 1 Surabaya & $100 \%$ & $100 \%$ \\
\hline 2 & SMKN 4 Surabaya & $100 \%$ & $100 \%$ \\
\hline 3 & SMKN 10 Surabaya & $99 \%$ & $100 \%$ \\
\hline
\end{tabular}

Dari data tabel 2 dan tabel 3 terlihat jelas bahwa walaupun peserta didik mempunyai pengetahuan dan keterampilan untuk menggunakan internet sebagai bekal untuk melakukan penjualan online tetapi peserta didik tidak melakukannya. Padahal kalau peserta didik melakukan penjualan online maka akan menghasilkan kinerja penjualan yang maksimal.

Hal ini sesuai dengan penelitian yang dilakukan oleh Arafat (2013) ditemukan bahwa Ada pengaruh Interpersonal Skill, Salesmanship Skill, Technical Skill dan Marketing Skill secara simultan terhadap kinerja penjualan. Dan didalam penelitian tersebut ditegaskan bahwa semakin baik interpersonal skill, Salesmanship Skill, Technical Skill Dan Marketing Skill diterapkan maka akan semakin meningkatkan kinerja penjualan.(Arafat, Rendy, 2013)

Menurut penelitian yang dilakukan oleh Islami, Augusty dan Ferdinand (2012), menyebutkan bahwa : hard skill (Keterampilan), Soft skill (Karakter bekerja), Motivasi berpengaruh positif dan signifikan terhadap kinerja tenaga penjualan, semakin tinggi hard skill (Keterampilan), Soft skill (Karakter bekerja), motivasi yang dimiliki tenaga penjual, maka semakin tinggi kinerja tenaga penjualan.

Penelitian yang dilakukan oleh Basir dkk. (2010) memeriksa dimensi keterampilan penjualan yaitu keterampilan interpersonal, salesmanship, teknis dan pemasaran berpengaruh terhadap kinerja tenaga penjual. Hasil dari penelitiannya menunjukkan bahwa penjual yang memiliki keterampilan interpersonal yang baik dapat meningkatkan kinerja penjualan secara 
signifikan. Selain itu, penelitian ini juga menunjukkan bahwa dalam lingkungan bisnis monopoli, keterampilan interpersonal memainkan peran yang sangat penting dalam kinerja tenaga penjual. Selain itu, untuk memiliki kesempatan membuat penjualan, setiap kontak interpersonal harus memiliki tujuan dan setiap upaya harus dilakukan untuk menghindari menciptakan transaksi menang-kalah.

Menurut penelitian yang dilakukan oleh Ahearne dkk. (2011) bahwa ada hasil positif Sales force automation / CRM customer relationship management (CRM), dengan penggunaan teknologi dan kinerja lengkung. Hal ini menunjukkan implikasi yang kuat. Untuk khususnya pada sampel, rata-rata, tampak bahwa peningkatan pemakaian teknologi akan memiliki efek positif pada kinerja penjualan . Pada penelitian tersebut bermanfat untuk memberikan informasi yang berharga kepada manajer untuk membimbing penjual tentang penggunaan teknologi mereka. Manajer dapat menggunakan informasi tersebut untuk diskusi berkala tentang bagaimana penjual tertentu dapat meningkatkan kinerja mereka dengan menggunakan teknologi untuk tingkat yang lebih besar atau lebih kecil.

Sesuai dengan penelitian yang dilakukan oleh Ahearne dan Lam (2011) menyebutkan jika kekuatan kinerja Penjualan adalah fungsi dari banyak variabel, beberapa di antaranya berada di bawah kendali para penjual dan beberapa yang tidak. Dan pada penelitian sebelumnya telah membuktikan bahwa kekuatan kinerja penjualan berasal dari interaksi dan sinergi antara upaya tenaga penjualan dan variabel bauran pemasaran lainnya.

Menurut Kotler dan Keller (2012) Saluran terbaru untuk berkomunikasi dan menjual secara ke pelanggan adalah saluran elektronik. Internet menyediakan peluang kepada pemasar dan konsumen untuk interaksi dan individualisasi yang jauh lebih besar .

Kemajuan teknologi informasi banyak membawa dampak positif bagi kemajuan dunia pendidikan dewasa ini. Khususnya teknologi komputer dan internet, baik dalam perangkat keras maupun perangkat lunak, memberikan banyak tawaran dan pilihan bagi dunia pendidikan untuk menunjang proses pembelajaran. Keunggulan yang ditawarkan bukan saja terletak pada faktor kecepatan untuk mendapatkan informasi namun juga fasilitas multimedia yang dapat membuat belajar lebih menarik, visual dan interaktif. Sejalan dengan perkembangan teknologi internet, banyak kegiatan pembelajaran yang dapat dilakukan dengan memanfaatkan teknologi ini.

Dalam permendiknas tersebut juga menjelaskan bahwa Pendidikan ditujukan untuk mengembangkan kecerdasan intelektual dan kecemerlangan akademik melalui pendidikan disiplin ilmu. Filosofi ini menentukan bahwa isi kurikulum adalah disiplin ilmu dan pembelajaran adalah pembelajaran disiplin ilmu (essentialism). (Permendikbud RI, Nomor 70 tahun 2013)

Dari pengembangan kecerdasan intelektual dan kecemerlangan akademik tersebut dapat dilihat dari hasil belajar peserta didik. Hasil belajar merupakan bagian terpenting dalam pembelajaran. Sudjana (2009) mendefinisikan hasil belajar peserta didik pada hakikatnya adalah perubahan tingkah laku sebagai hasil belajar dalam pengertian yang lebih luas mencakup bidang kognitif, afektif, dan psikomotorik. Dimyati dan Mudjiono (2006) juga menyebutkan hasil belajar merupakan hasil dari suatu interaksi tindak belajar dan tindak 
mengajar. Dari sisi guru, tindak mengajar diakhiri dengan proses evaluasi hasil belajar. Dari sisi peserta didik, hasil belajar merupakan berakhirnya pengajaran dari puncak proses belajar.

Sektor pendidikan juga memerlukan solusi teknologi informasi untuk memperlancar proses belajar mengajar. Kehadiran perangkat lunak pendidikan dan hiburan membuat proses pendidikan menjadi lebih efektif. Dengan perantara perangkat lunak pendidikan, peserta didik belajar dengan suasana yang lebih menyenangkan.

Teknologi komputer khususnya penggunaan blog dengan kemampuannya mengolah dan menyajikan tayangan multimedia (teks, grafis, gambar, suara dan movie) memberikan peluang baru untuk melakukan penjualan . Menurut Porto (2010), "a blog is a personal or business website in which the author posts information including text, photos, videos, or audio recordings, and may also display gadgets like a visitor counter, slideshow, or related ads."

Berdasarkan penelitian Akbar (2000) ternyata kesuksesan seseorang tidak ditentukan semata-mata oleh pengetahuan dan kemampuan teknis (hard skill) saja, tetapi lebih oleh kemampuan mengelola diri dan orang lain (soft skill). Penelitian ini mengungkapkan, kesuksesan hanya ditentukan sekitar $20 \%$ oleh hard skill dan sisanya $80 \%$ oleh soft skill. Bahkan orang-orang tersukses di dunia bisa berhasil dikarenakan lebih banyak didukung kemampuan soft skill dari pada hard skill. Hal ini mengisyaratkan bahwa mutu pendidikan karakter termasuk karakter kewirausahaan peserta didik sangat penting untuk segera ditingkatkan.

Peserta didik SMK Kompetensi Kejuruan Pemasaran dituntut dan wajib mengikuti semua materi pelajaran yang ditempatkan pada struktur tersebut. Peserta didik dilatih dan dibiasakan untuk mengapresiasikan karyanya untuk ditampilkan pada umum salah satunya melalui media internet.

Secara ringkas pada kurikulum tersebut peserta didik dibekali dengan kemampuan untuk mengenal dan mengoperasikan komputer termasuk dalam penggunaan internet. Salah satu harapan yang diinginkan adalah peserta didik mampu melakukan penjualan produk secara online.

Berhubung saat ini sebagian besar orang umum termasuk peserta didik SMK Kompetensi Kejuruan Pemasaran sudah banyak yang melek teknologi internet, tentunya strategi marketing secara online akan berbeda bahkan lebih besar kemungkinan berhasilnya dalam penjualan suatu produk dibandingkan dengan tidak online.

Berdasarkan penjelasan di atas, terlihat dengan jelas bahwa walaupun peserta didik kelas 10 PMSR sudah terampil menggunakan internet serta mampu menggunakan media sosial maupun blog sebagai sarana untuk dapat melakukan penjualan produk secara online (kinerja penjualan online) menurut Kotler dan Keller (2012), "Kinerja penjualan online adalah hasil pencapaian pekerjaan terhadap standar yang telah ditentukan pada penjualan online". tetapi pada kenyataanynya mereka tidak memanfaatakan kesempatan itu untuk menggunakan pada kegiatan penjualan produk secara online seperti tampak pada tabel 2. dan tabel 3. Oleh karena itu peneliti tertarik untuk mengadakan penelitian tentang "Pengaruh Hasil Belajar Pemasaran Online dan Hasil Belajar Kewirausahaan Terhadap Kinerja Penjualan Online Peserta Didik SMK Negeri Surabaya." 


\section{METODE PENELITIAN}

Jenis penelitian ini adalah penelitian eksplanatori/eksplanatif (eksplanative research). Penelitian ini ditujukan untuk mengetahui hubungan atau pengaruh antara dua variable atau lebih yaitu pengaruh hasil belajar pemasaran online dan hasil belajar kewirausahaan terhadap kinerja penjualan online. Sedangkan metode yang digunakan dalam penelitian ini adalah penelitian kuantitatif karena mengembangkan dan menggunakan model matematis dalam pengukuran data melalui penghitungan ilmiah yang berasal dari sampel orang yang diminta menjawab atas sejumlah pertanyaan tentang survey untuk menentukan frekwensi atau prosentase tanggapan seseorang.

Metode penelitian kuantitatif dapat diartikan sebagai metode penelitian yang berlandaskan pada filsafat positivisme digunakan untuk meneliti pada populasi atau sampel tertentu, tehnik pengambilan sampel pada umumnya dilakukan secara random, pengumpulan data menggunakan instrument penelitian, analisis data bersifat kuantitatif / statistik dengan tujuan untuk menguji hipotesis yang telah ditetapkan (Sugiyono, 2013).

Jenis penelitian yang peneliti gunakan berupa penelitian kuantitatif dengan menggunakan regresi linear berganda, dalam penelitian ini terdapat dua variable bebas dan satu variable terikat yaitu : Hasil belajar pemasaran online $\left(\mathrm{X}_{1}\right)$, Hasil belajar kewirausahaan $\left(\mathrm{X}_{2}\right)$ dan Kinerja penjualan online $(\mathrm{Y})$.

Selanjutnya penelitian ini menganalisis kedua variable bebas, adapun hasil belajar pemasaran online adalah hasil yang ditunjukkan dari suatu interaksi tindak belajar dan biasanya ditunjukkan dengan nilai tes yang diberikan guru pada mata pelajaran pemasaran online. Hasil belajar pemasaran online berupa ulangan harian mata pelajaran pemasaran online yang dilaksanakan pada hari Rabu, 18 Maret 2015. Hal ini sesuai dengan pendapat Sudjana (2004) Indikator hasil belajar kewirausahaan adalah sebagai berikut :

1) Ranah Kognitif,

2) Ranah Afektif,

3) Ranah Psikomotor,

Hasil belajar kewirausahaan adalah hasil yang ditunjukkan dari suatu interaksi tindak belajar dan biasanya ditunjukkan dengan nilai tes yang diberikan guru pada mata pelajaran kewirausahaan. Hasil belajar kewirausahaan berupa ulangan harian mata pelajaran kewirausahaan yang dilaksanakan pada Senin, 16 Maret 2015. Hal ini sesuai dengan yang dikemukakan oleh Sudjana (2004) Indikator hasil belajar kewirausahaan adalah sebagai berikut :

1) Ranah Kognitif,

2) Ranah Afektif,

3) Ranah Psikomotor,

Kinerja penjualan online adalah hasil pencapaian pekerjaan terhadap standar yang telah ditentukan pada penjualan online. Hal ini sesuai dengan yang disampaikan oleh Kotler dan Keller (2012) bahwa terdapat sembilan indikator kinerja penjualan, tetapi hanya tujuh indikator yang sesuai dengan penelitian ini yaitu :

1. Jumlah rata - rata penjualan pada setiap harinya 
2. Jumlah rata - rata penjualan pada setiap transaksi

3. Jumlah rata - rata pendapatan pada setiap transaksi

4. Jumlah rata - rata biaya pada setiap transaksi

5. Prosentase pesanan pada setiap 10 kali transaksi

6. Jumlah pelanggan baru pada setiap minggunya

7. Jumlah konsumen yang membatalkan pembelian pada setiap minggunya.

Populasi dalam penelitian ini adalah siswa kelas 10 PMSR SMK Negeri 1, SMK Negeri 4 dan SMK Negeri 10 Surabaya tahun pelajaran 2014 / 2015 sebanyak 200 peserta didik. Dengan sampel sebanyak 135 peserta didik ditetapkan dengan tehnik proporsional. Data dikumpulkan dengan penyebaran kuisioner dan dokumentasi. Kuisioner disusun berdasarkan variable penelitian dan indikator penelitian dengan skala pengukuran instrument menggunakan skala linkert dan rating scale. Uji asumsi klasik yang dilakukan dalam penelitian ini adalah uji linieritas, uji multikolinieritas, uji normalitas dan uji heteroskedastisitas.

Tehnik analisis menggunakan analisis uji statistik $F$ dan uji t. Uji $F$ digunakan untuk mengetahui apakah hasil belajar pemasaran online dan hasil belajar kewirausahaan mempunyai pengaruh yang sama terhadap Kinerja penjualan online. Sedangkan Uji t digunakan untuk menguji pengaruh secara parsial hasil belajar pemasaran online dan hasil belajar kewirausahaan terhadap kinerja penjualan online. Analisis data menggunakan SPSS 22 dengan ketentuan (Ghozali, 2006).

\section{HASIL PENELITIAN DAN PEMBAHASAN}

Uji linieritas merupakan prosedur yang digunakan untuk mengetahui status linier atau tidaknya suatu distribusi data penelitian, atau dikatakan apakah antar dependent variabel dan independent variabel tersebut linier.

\begin{tabular}{|c|c|c|c|c|c|c|c|}
\hline \multicolumn{8}{|c|}{ ANOVA Table } \\
\hline & & & $\begin{array}{l}\text { Sum of } \\
\text { Squares }\end{array}$ & $\mathrm{df}$ & $\begin{array}{l}\text { Mean } \\
\text { Square }\end{array}$ & $\mathrm{F}$ & Sig. \\
\hline \multirow{3}{*}{$\begin{array}{l}\text { KINERJAPENJUA } \\
\text { LANONLINE * } \\
\text { HASILBELAJARP }\end{array}$} & \multirow{3}{*}{$\begin{array}{l}\text { Between } \\
\text { Groups }\end{array}$} & (Combined) & 275.687 & 15 & 18.379 & .858 & .612 \\
\hline & & Linearity & .173 & 1 & .173 & .008 & .928 \\
\hline & & Deviation from Linearity & 275.514 & 14 & 19.680 & .918 & .541 \\
\hline \multirow{2}{*}{$\begin{array}{l}\text { EMASARANONLI } \\
\text { NE }\end{array}$} & \multicolumn{2}{|c|}{ Within Groups } & 2550.239 & 119 & 21.431 & & \\
\hline & \multicolumn{2}{|l|}{ Total } & 2825.926 & 134 & & & \\
\hline
\end{tabular}

Berdasarkan hasil uji menunjukkan bahwa nilai signifikasi variabel hasil belajar pemasaran online yaitu 0.541 yang menandakan bahwa nilai tersebut lebih besar dari 0.05 , yang artinya terdapat hubungan linier secara signifikan antara variabel hasil belajar pemasaran online $\left(\mathrm{X}_{1}\right)$ dengan kinerja penjualan online (Y). sedangkan nilai signifikasi variabel hasil belajar kewirausahaan $\left(\mathrm{X}_{2}\right)$ yaitu 0.665 yang menandakan bahwa nilai tersebut lebih besar dari 0.05 , yang artinya terdapat hubungan linier secara signifikan antara variabel hasil 
belajar kewirausahaan $\left(\mathrm{X}_{2}\right)$ dengan kinerja penjualan online $(\mathrm{Y})$. Berdasarkan hasil uji linieritas pada masing - masing variabel $\mathrm{X}$ dengan variabel $\mathrm{Y}$ terjadi hubungan linieritas karena nilai signifikasinya lebih besar dari 0.05 , sehingga dalam penelitian ini tidak terjadi masalah linieritas.

\begin{tabular}{|c|c|c|c|c|c|c|c|}
\hline \multicolumn{8}{|c|}{ ANOVA Table } \\
\hline & & & $\begin{array}{l}\text { Sum of } \\
\text { Squares }\end{array}$ & df & $\begin{array}{l}\text { Mean } \\
\text { Square }\end{array}$ & $\mathrm{F}$ & Sig. \\
\hline \multirow{5}{*}{$\begin{array}{l}\text { KINERJAPENJUA } \\
\text { LANONLINE * } \\
\text { HASILBELAJARK } \\
\text { EWIRAUSAHAAN }\end{array}$} & \multirow{3}{*}{$\begin{array}{l}\text { Between } \\
\text { Groups }\end{array}$} & (Combined) & 190.856 & 12 & 15.905 & .736 & .714 \\
\hline & & Linearity & 6.965 & 1 & 6.965 & .322 & .571 \\
\hline & & Deviation from Linearity & 183.890 & 11 & 16.717 & .774 & .665 \\
\hline & \multicolumn{2}{|c|}{ Within Groups } & 2635.070 & 122 & 21.599 & & \\
\hline & \multicolumn{2}{|l|}{ Total } & 2825.926 & 134 & & & \\
\hline
\end{tabular}

Hasil uji multikoliniearitas menjelaskan bahwa nilai tolerance dan VIF yang dihasilkan oleh variabel Hasil belajar pemasaran online $\left(\mathrm{X}_{1}\right)$ adalah 1,000 untuk nilai tolerance (tepat angka 1) dan nilai VIF adalah 1,000 (kurang dari angka 10), sedangkan variabel Hasil belajar kewirausahaan (X2) adalah 1,000 untuk nilai tolerance (tepat angka 1) dan nilai VIF adalah 1,000 (kurang dari angka 10) sehingga antara variabel bebas tidak terjadi multikolinieritas.

Hasil uji normalitas dapat disimpulkan bahwa nilai KolmogorovSmirnov yang dihasilkan dari variabel bebas adalah 0,254 dan 0,573. Tingkat yang dihasilkan tersebut lebih dari $5 \%$ yang berarti residual mengikuti distribusi normal, sehingga variable hasil belajar pemasaran online (X1) dan hasil belajar kewirausahaan (X2) dan kinerja penjulan online(Y) dengan sendirinya berdistribusi niormal.

Hasil uji heteroskedastisitas berdasarkan output Scatterplot terlihat bahwa titik - titik menyebar dan tidak membentuk pola tertentu yang jelas, sehingga dapat disimpulkan bahwa tidak terjadi masalah heterokedastisitas

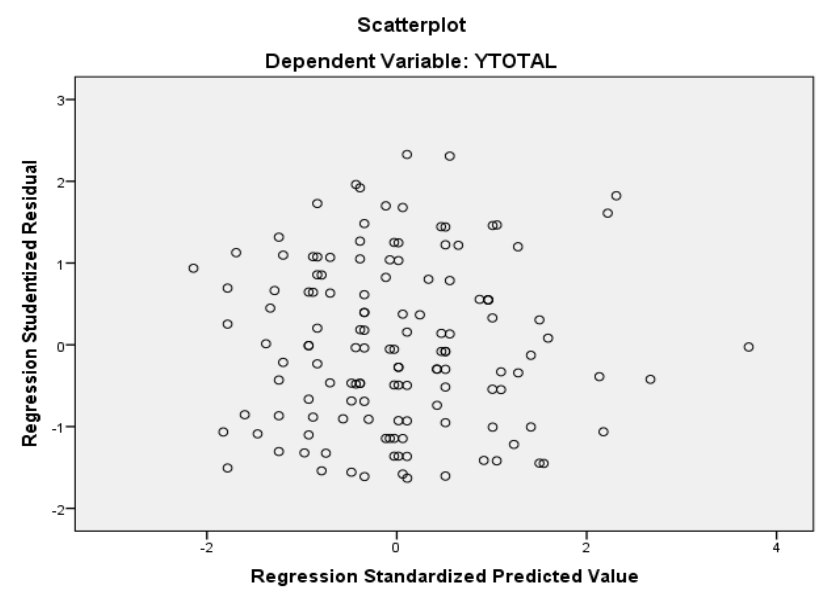

Model regresi yang diperoleh berdasarkan hasil penelitian, dapat dituliskan dalam persamaan regresi adalah sebagai berikut : $\mathrm{Y}=21,561+$ $0,010 X_{1}+0,104 X_{2}$. Dari persamaan tersebut, kedua variabel bebas memiliki koefisien regresi dengan arah positif. Hal ini berarti bahwa semakin tinggi hasil 
belajar pemasaran online, hasil belajar kewirausahaan akan meningkatkan kinerja penjulan online peserta didik. Hasil uji $\mathrm{F}$ berdasarkan uji ANOVA atau uji statistic F, model $\mathrm{F}$ menunjukkan nilai $\mathrm{F}$ sebesar 2,706 dengan signifikasi 0,000 lebih kecil dari 5\%, hal ini berarti bahwa kinerja penjualan online dapat dijelaskan oleh variable hasil belajar pemasaran online dan hasil belajar kewirausahaan secara bersama - sama atau dengan kata lain semua variabel bebas secara bersama - sma merupakan penjelas yang signifikan pada variabel terikat.

\begin{tabular}{|c|c|c|c|c|c|c|c|c|}
\hline \multicolumn{9}{|c|}{ Coefficients $^{\mathrm{a}}$} \\
\hline & \multirow{2}{*}{ Model } & \multicolumn{2}{|c|}{$\begin{array}{c}\text { Unstandardized } \\
\text { Coefficients }\end{array}$} & \multirow{2}{*}{$\begin{array}{c}\begin{array}{l}\text { Standardized } \\
\text { Coefficients }\end{array} \\
\text { Beta }\end{array}$} & \multirow[t]{2}{*}{$\mathrm{t}$} & \multirow[t]{2}{*}{ Sig. } & \multicolumn{2}{|c|}{$\begin{array}{c}\text { Collinearity } \\
\text { Statistics }\end{array}$} \\
\hline & & $\mathrm{B}$ & Std. Error & & & & Tolerance & VIF \\
\hline \multirow[t]{3}{*}{1} & (Constant) & 21.561 & 18.579 & & 1.161 & .248 & & \\
\hline & HASILBELAJARPEMASARANONLINE & .010 & .113 & .008 & .092 & .927 & 1.000 & 1.000 \\
\hline & HASILBELAJARKEWIRAUSAHAAN & .104 & .182 & -.050 & -.571 & .569 & 1.000 & 1.000 \\
\hline
\end{tabular}

\begin{tabular}{|l|l|r|r|r|r|r|}
\hline \multicolumn{2}{|c|}{ Model } & $\begin{array}{c}\text { Sum of } \\
\text { Squares }\end{array}$ & \multicolumn{1}{c|}{ df } & \multicolumn{1}{c|}{$\begin{array}{c}\text { Mean } \\
\text { Square }\end{array}$} & \multicolumn{1}{c|}{ F } & \multicolumn{1}{c|}{ Sig. } \\
\hline \multirow{2}{*}{1} & Regression & 1571.418 & 2 & 785.709 & $2.706 \mathrm{E} 3$ & $.000^{\mathrm{a}}$ \\
\cline { 2 - 7 } & Residual & 37.740 & 130 & .290 & & \\
\cline { 2 - 5 } & Total & 1609.158 & 132 & & & \\
\hline
\end{tabular}

Koefisien determinasi ( $R$-Square) yang dihasilkan dalam penelitian ini sebesar 0,976 yang berasal dari 1571,418:1609,158. Hal ini menunjukkan hasil belajar pemasaran online $\left(\mathrm{X}_{1}\right)$ dan hasil belajar kewirausahaan $\left(\mathrm{X}_{2}\right)$ berpengaruh pada kinerja penjualan online (Y) sebesar 97,6\% sedangkan sisanya dipengaruhi oleh variabel lain yang tidak dibahas pada penelitian ini.

Uji parsial menunjukkan semua variabel mempunyai pengaruh yang signifikan. Uji parsial menunjukkan nilai t-hitung pada variabel hasil belajar pemasaran online $\left(\mathrm{X}_{1}\right)$ sebesar 17,052 lebih besar dari t - tabel 1,960 dan nilai signifikasi 0,000 lebih kecil dari 0,05. Nilai t-hitung pada variabel hasil belajar kewirausahaan $\left(\mathrm{X}_{2}\right)$ sebesar 19,598 lebih besar dari $\mathrm{t}$ - tabel 1,960 dan nilai signifikasi 0,000 lebih kecil dari 0,05. Dengan tingkat signifikan yang kurang dari $5 \%$ berarti menunjukkan bahwa hasil belajar pemasaran online $\left(\mathrm{X}_{1}\right)$ dan hasil belajar kewirausahaan $\left(\mathrm{X}_{2}\right)$ secara parsial berpengaruh signifikan pada pada kinerja penjualan online $(\mathrm{Y})$.

Berdasarkan hasil analisis menunjukkan bahwa hasil belajar pemasaran online berpengaruh signifikan pada kinerja penjualan online. Hasil tersebut mempunyai makna bahwa setiap perubahan variabel hasil belajar pemasaran online akan berpengaruh positif pada kinerja penjualan online. Pada uji regresi menunjukkan angka positif, hal ini pengaruh yang timbul searah, dimana setiap naiknya variabel hasil belajar pemasaran online maka kinerja penjualan online 
akan mengalami peningkatan dengan asumsi variabel hasil belajar kewirausahaan adalah konstan.

Hasil belajar sangat diperlukan oleh peserta didik , karena dengan hasil belajar peserta didik akan menghasilkan suatu hasil kerja atau kinerja sesuai dengan harapan yang ditetapkan. Hal ini sesuai dengan hasil penelitian. Sebagian besar peneliti menyatakan jika hasil belajar dapat berpengaruh pada kinerja yang diharapkan. Berikut hasil penelitian yang disampaikan oleh beberapa ahli.

Hasil penelitian Setiawan (2003) "Menyimpulkan bahwa kinerja tenaga penjualan dapat dicapai melalui indikator variabel sistem kontrol dan sinergi aktivitas tenaga penjualan. Dengan demikian faktor-faktor yang mempengaruhi kinerja tenaga penjualan yang berupa indikator variabel sistem kontrol dan sinergi aktivitas tenaga penjualan, dalam penelitian ini telah mendapatkan justifikasi dari hasil analisis.

Hasil penelitian O’Neila, Harold F, Wainessa, Richard and Baker, Eva L. (2005) . menunjukkan jika dalam hasil belajar dari permainam/game yang berbasis komputer akan meningkatkan kinerja yang baik. Artinya peserta didik akan memiliki kinerja penjualan yang tinggi apabila hasil belajar permainan yang berbasis komputer dilakukan dengan baik

Hasil penelitian yang dilakukan oleh Grodner (2011). Penelitian ini menguji pengaruh pekerjaan rumah pada hasil belajar peserta didik. Percobaan lapangan ini melibatkan dalam kelas yang sama, secara acak dan menugaskan kepada mahasiswa diwajibkan dan tidak diperlukan untuk menyelesaikan pekerjaan rumah. Kedua kelompok menghadiri kuliah yang sama, menerima pekerjaan yang identik tugas, dan memiliki akses ke kunci jawaban pekerjaan rumah. Dalam penelitian itu ditemukan bukti bahwa pekerjaan rumah(PR) bermanfaat bagi belajar siswa. Secara khusus, kelompok peserta didik (25 peserta didik) memiliki nilai rata-rata evaluasi 5\% sampai 6\% lebih tinggi daripada kelompok peserta didik yang tidak mengerjakan pekerjaan rumah (PR). Efek yang paling menonjol bagi peserta didik yang awalnya hasil belajarnya buruk sekarang rata - rata hasil belajarnya 9\% sampai $13 \%$ lebih tinggi dibandingkan dengan peserta didik yang tidak mengerjakan pekerjaan rumah (PR).

Hasil penelitian yang dilakukan oleh Yamarik (2004) ditemukan bahwa dengan menggunakan pembelajaran kolaboratif mengangkat kehadiran dan kinerja dalam kelompok terkait kegiatan. Meskipun pembelajaran kolaboratif tidak ditemukan secara langsung meningkatkan prestasi akademik, tetapi ditemukan bahwa dengan jumlah kehadiran peserta didik yang lebih banyak dalam pembelajaran tersebut meningkatkan nilai ujian. Secara keseluruhan, hasil penelitian ini menyatakan bahwa peserta didik yang sering hadir dalam pembelajaran kolaboratif secara tidak langsung dapat meningkat prestasi akademiknya.

Hasil penelitian yang dilakukan oleh Basir dkk (2010) menyebutkan bahwa penelitian ini telah menetapkan untuk memeriksa dimensi keterampilan penjualan yaitu keterampilan interpersonal, salesmanship, teknis dan pemasaran berpengaruh terhadap kinerja tenaga penjual. Berdasarkan pada tinjauan literatur yang luas, empat hipotesis berkaitan dengan penjualan keterampilan dimensi dan penjual hubungan kinerja yang mengemukakan. 
Subyek atau responden penelitian adalah penjual di TM Berhad. Dalam penelitian tersebut sebanyak 114 responden dari ukuran sampel dari 270 berpartisipasi dalam survei. Dari empat Hipotesis sedang diperiksa, dukungan ditemukan hanya satu hipotesis yang menunjukkan bahwa ada adalah hubungan yang signifikan antara kemampuan interpersonal dan kinerja tenaga penjual. Meskipun beberapa temuan yang tidak biasa, hasil dari penelitian ini menunjukkan bahwa penjual yang memiliki baik keterampilan interpersonal dapat secara signifikan meningkatkan kinerja penjualan. Selain itu, penelitian ini menunjukkan bahwa dalam lingkungan bisnis monopoli, keterampilan interpersonal memainkan peran penting dalam kinerja tenaga penjual.

Berdasarkan penelitan yang dilakukan oleh Fatullah (2008) dapat diambil beberapa kesimpulan sebagai berikut:

a. Informasi yang paling banyak dibutuhkan oleh penghobi anggrek dari forum online adalah informasi yang berkaitan dengan koleksi yang dimiliki oleh anggota forum.

b. Bentuk produk informasi yang paling baik dipasarkan secara online adalah ebook dengan format PDF, sebab untuk membuatnya hampir tidak dibutuhkan biaya dan kemampuan khusus. Disisi lain format tersebut aman, mudah, dan aplikasi untuk membaca format tersebut dapat di download secara gratis. Memperoleh produk informasi secara online dianggap belum mudah bagi sebagian besar penghobi anggrek, hal ini dapat dilihat dari banyaknya penghobi yang masih ragu dan kehilangan minat setelah mengetahui prosedurnya. Sebagian besar penghobi anggrek juga tidak menggunakan fasilitas download yang menghemat waktu dan biaya untuk memperoleh produknya.

c. Faktor - faktor yang mempengaruhi penghobi anggrek untuk membeli informasi online adalah tingkat kepercayaan pembeli, kemudahan situs untuk ditemukan menggunakan search engine, tampilan situs, dan kredibilitas situs penjual.

d. Rasio biaya dan pendapatan adalah 38,53 . Sedangkan efisiensi pemasaran sebesar $52 \%$.

Pada bagian ini ditemukan bahwa :

1. nilai mata pelajaran pemasaran online peserta didik bervariatif dan semua diatas KKM. Namun terdapat 12 atau $(8,88 \%)$ peserta didik yang mendapat grade amat baik $(A=90-100)$, sedangkan sisanya 123 atau $(91,12 \%)$ mendapat grade baik $(B=75-89)$. Pada intinya semua peserta didik mempunyai nilai hasil belajar pemasaran online diatas KKM namun jumlah peserta didik yang mendapatkan nilai amat baik jauh lebih sedikit dari jumlah peserta didik yang nilainya baik.

2. Jumlah rata-rata penjualan peserta didik pada setiap harinya $47 \%$ berkisar antara $\mathrm{Rp} 0,-\mathrm{s} / \mathrm{d} \operatorname{Rp} 50.000$,- artinya nilai penjualan peserta didik minim

3. Jumlah rata - rata pendapatan peserta didik pada setiap transaksi $87 \%$ berkisar $\mathrm{Rp} \mathrm{0,-} \mathrm{s/d} \mathrm{Rp} \mathrm{50.000,-} \mathrm{artinya} \mathrm{nilai} \mathrm{pendapatan} \mathrm{peserta} \mathrm{didik}$ minim

4. Jumlah pelanggan baru pada setiap minggunya $98 \%$ berkisar $0-2$ pelanggan artinya jumlah pelanggan peserta didik ada walaupun sedikit 
Berdasarkan hasil analisis menunjukkan bahwa hasil belajar kewirausahaan berpengaruh signifikan pada kinerja penjulan online . Hasil tersebut mempunyai makna bahwa setiap perubahan variabel hasil belajar kewirausahaan akan berpengaruh positif pada kinerja penjualan online. Nilai koefisien regresi positif menunjukkan pengaruh yang timbul searah, dimana setiap naiknya variabel hasil belajar kewirausahaan maka kinerja penjualan online akan mengalami peningkatan dengan asumsi variabel hasil belajar pemasaran online adalah konstan.

Hasil belajar kewirausahaan berpengaruh signifikan pada kinerja penjualan online peserta didik SMK Negeri Surabaya didukung dengan proses belajar mengajar yang mendidik para peserta didik untuk praktek berjualan disekolah secara langsung. Hal ini merupakan implementasi kegiatan kewirausahaan skala kecil. .

Berdasarkan hasil penelitian Rauch dkk. (2004) menunjukkan bahwa EO (Orientasi kewirausahaan) memiliki hubungan yang sama dengan yang dirasakan keuangan kinerja, dirasakan indikator non-keuangan kinerja, dan arsip kinerja. Hal ini juga ditetapkan dalam literatur bahwa kegiatan strategis tersirat oleh sebuah EO (Orientasi kewirausahaan), seperti pengembangan produk baru, memiliki konsekuensi keuangan. Implikasi dari Temuan ini adalah bahwa fungsi utama dari orientasi kewirausahaan adalah untuk meningkatkan hasil keuangan bukan untuk memajukan tujuan lain. Namun, meskipun korelasi antara EO (Orientasi kewirausahaan) dan keduanya dianggap dan kinerja keuangan arsip itu sangat positif, itu tidak signifikan lebih besar daripada korelasi antara EO (Orientasi kewirausahaan) dan dirasakan ukuran kinerja non-keuangan. Ini menunjukkan bahwa hubungan EO (Orientasi kewirausahaan) dan kinerja yang kuat tidak hanya untuk ukuran yang berbeda dari EO (Orientasi kewirausahaan), seperti yang dilaporkan di atas, tetapi juga perbedaan dalam pengukuran kinerja.

Hasil penelitian yang dilakukan oleh Arshada dkk (2013) menunjukkan bahwa hanya empat dimensi EO berpengaruh terhadap kinerja bisnis; yaitu : a. inovasi; b. proactiveness; c.berani mengambil risiko, d.agresivitas. Artinya Kinerja penjualan dalam berbisnis ini meningkat apabila didukung dengan inovasi, keaktifan para pekerja, keberanian dalam menghadapi resiko dan keagresipan dalam bekerja

Hasil penelitian Gompers dkk (2010) menunjukkan adanya kinerja ketekunan dalam kewirausahaan dan mempelajari sumbernya. Dalam penelitian tersebut menemukan bukti bahwa keterampilan, dan daya imajinasi dalam keterampilan, sangat mendorong pada kinerja penjualan.

Hasil penelitian Karacaoglu dkk (2012) menunjukkan bahwa Corporate entrepreneurship dapat menyebabkan banyak hasil positif dalam tingkat organisasi dan itu adalah konsep belajar oleh banyak peneliti dalam beberapa tahun terakhir. Kewirausahaan korporasi dengan dimensi yang berbeda dipelajari dan terkait dengan kinerja operasi dalam literatur. Dalam penelitian ini, efek kewirausahaan korporasi pada kinerja 140 perusahaan publik dikutip di ISE telah ditunjukkan dengan empiris penelitian. Dalam studi tersebut, model yang diuji semua telah dikembangkan sesuai dengan literatur yang berhubungan. Setelah pengujian model yang dikembangkan dengan model persamaan struktural dengan program LISREL; ditemukan bahwa lima dimensi 
model, yang terdiri dari inovasi, proaktif, pengambilan risiko, otonomi dan kompetitif dimensi agresivitas (dua terakhir yang ditambahkan kemudian), tidak memiliki efek positif yang diharapkan pada kinerja. Hal itu juga terlihat bahwa meskipun model memiliki kebaikan diterima fit statistik, itu sedikit yang menjelaskan hubungan atau interaksi antara variabel. Model alternatif yang dikembangkan dalam penelitian ini, adalah disebut sebagai model asli dalam literatur. Menurut hasil analisis model ini, perusahaan kewirausahaan memiliki kekuatan penjelas yang kuat dari kinerja perusahaan seperti yang diperkirakan. Goodness of fit statistik model ini juga sangat baik dan pada tingkat yang diharapkan. Untuk alasan ini, model yang mencakup asli dimensi kewirausahaan perusahaan, yang proaktif, inovasi dan pengambilan risiko, diterima.

Berdasarkan hasil analisis menunjukkan bahwa hasil belajar pemasaran online dan hasil belajar kewirausahaan berpengaruh signifikan pada kinerja penjualan online. Hasil tersebut mempunyai makna bahwa setiap perubahan variabel hasil belajar pemasaran online dan hasil belajar kewirausahaan akan berpengaruh positif pada kinerja penjualan online. Nilai koefisien regresi positif menunjukkan pengaruh yang timbul searah, dimana setiap naiknya variabel hasil belajar pemasaran online dan hasil belajar kewirausahaan maka kinerja penjualan online akan mengalami peningkatan dengan asumsi variabel lain dianggap tetap atau given.

Hasil belajar pemasaran online dan hasil belajar kewirausahaan berpengaruh signifikan pada kinerja penjulan online peserta didik SMK Negeri Surabaya. Berdasarkan data dari kedua variabel diatas dapat disimpulkan hasil belajar pemasaran online dan hasil belajar kewirausahaan memberikan kontribusi dalam meningkatkan kinerja penjualan online, meskipun terdapat kekurangan pada setiap variabelnya maka perlu adanya perbaikan untuk setiap kekurangan yang ada.

\section{SIMPULAN}

Berdasarkan hasil penelitian diatas dapat disimpulkan bahwa, ada pengaruh signifikan hasil belajar pemasaran online terhadap kinerja penjualan online peserta didik SMK Negeri Surabaya. Hal ini berarti peningkatan hasil belajar pemasaran online peserta didik akan diikuti juga dengan peningkatan kinerja penjualan onlinenya. Ada pengaruh signifikan hasil belajar kewirausahaan terhadap kinerja penjualan online peserta didik SMK Negeri Surabaya. Hal ini berarti peningkatan hasil belajar kewirausahaan peserta didik akan diikuti juga dengan peningkatan kinerja penjualan online. Ada pengaruh signifikan secara bersama - sama hasil belajar pemasaran online dan hasil belajar kewirausahaan terhadap kinerja penjualan online. Dengan demikian jika hasil belajar pemasaran online dan hasil belajar kewirausahaan meningkat secara bersama - sama, maka kinerja penjualan online akan meningkat.

\section{DAFTAR RUJUKAN}

Ahearne, Michael , \& Lam, Son K. , (2011): "Sales Force Performance: A Typology And Future Research Priorities", C.T. Bauer College of 
Business,

Ahearne, Michael, and Srinivasan, Narasimhan, and Luke Weinstein,(2005), "Effect Of Technology On Sales Performance: Progressing From Technology Acceptance To Technology Usage And Consequence"; Journal of Personal Selling \& Sales Management, vol. XXIV, no. 4, fall 2004, pp. 297-310.

Akbar, Ali Ibrahim., (2000), Membangun Spirit Entrepreneur Muda Indonesia, Jakarta, Gramedia.

Arafat, Rendy. (2013) $\square$. Pengaruh Dimensi Sales Skill Terhadap Kinerja Penjualan, Maj 2 (1) (2013) Management Analysis Journal

Arshada, Azlin Shafinaz; Amran Raslib, Afiza Azura Arshade, Zahariah Mohd Zainc;(2013)," The Impact of Enterpreneurial Orientation on Business Performance: A Study of Technology - based SMEs in Malaysia”. Jurnal Elsevier.

Basir, Mohd Sah, \& Ahmad,Syed Zamberi, \& Kitchen, J; (2010), ; "The Relationship Between Sales Skills And Salesperson Performance: An Empirical Study In The Malaysia Telecommunications Company"; International Journal Of Management And Marketing Research, Volume 3, Number 1, 2010

Dimyati dan Mudjiono., (2006), Belajar dan Pembelajaran, Jakarta : Rineka Cipta.

Fatullah, M. Fikri.(2008) Analisis Peluang Pemasaran Online Produk Informasi Digital Tanaman Anggrek (Tesis tidak dipublikasikan). Universitas Sumatra Utara, Medan

Ghozali, Imam. 2006. "Aplikasi Analisis Multivariate Dengan Program SPSS". Semarang. Badan Penerbit Undip

Gompers, P, Kovner, A, Lerner, J, Scharfstein,D, (2010) "Performance Persistence In Entrepreneurship “, National Bureau of Economic Research, Cambridge, ,2010

Gredler, Margareth E., (1996), Learning and Instruction ( Teori dan Aplikasi), Jakarta : Prenada Media Group.

Grodner, Andrew, Rupp Nicholas G. (2011). "The Role of Homework in Student Learning Outcomes: Evidence from a Field Experiment"; Department Economics, 3 January 2011

Korhan Karacaoglu, Ali Bayrakdaroğlu \& Firat Botan San ;(2012); “The Impact of Corporate Entrepreneurship on Firms' Financial Performance: Evidence from Istanbul Stock Exchange Firms" International Business Research; Vol. 6, No. 1; 2013 ISSN 1913-9004 E-ISSN 1913-9012 Published by Canadian Center of Science and Education

Kotler, Philip and Keller, Kevin Lane.(2012) . Marketing Management (14Edition). New Jersey: Pearson Education, Inc 
Kotler, Philip, (1990). Manajemen Pemasaran, Analisis, Perencanaan Dan Pengendalian, Jilid 1, Edisi Kelima. Jakarta : Penerbit Erlangga.

Lumpkin G.T. and Dess, G.G. . (2003). Strategic management: Creating competitive advantages. New York : McGraw-Hill Higher Education.

O’Neila, Harold F., Richard Wainessa and Eva L. Baker (2005)“Classification of learning outcomes: evidence from the computer games literature" The Curriculum Journal, Vol. 16, No. 4, December 2005, pp. 455 - 474

Permendikbud RI, Nomor 70 tahun 2013

Porto, Heather Wright. (2010). Beginning Google Blogger. New York: Apress

Rauch, Andreas, \& Wiklund, Johan, \& Lumpkin, G. T., \& Frese, Michael, (2004); "Entrepreneurial orientation and business performance: an assessment of past research and suggestions for the future" RSM Erasmus University Department of Entrepreneurship and New Business Venturing Burg. 2004

Setiawan, Andi (2003), “Analisis Kinerja Tenaga Penjualan Berdasarkan Sistem Kontrol Dan Sinergi Aktivitas Tenaga Penjualan”(Studi empiris Tenaga penjualan pada distributor farmasi di kota Semarang), Jurnal Sains Pemasaran Indonesia. Volume II, No. 1, Mei 2003, halaman 33 52

Sudjana, N., (2009), Penilaian Hasil Proses Belajar-Mengajar, Bandung: PT Remaja Rosdakarya,.

Sudjana, Nana. (2004). Dasar-Dasar Proses Belajar Mengajar. Bandung. Sinar Baru Al Gensindo

Sugiyono. (2013). Metode Penelitian Pendidikan. Bandung. Alfabeta

Yamarik, Steven. (2004)." Does Collaborative Learning Improve Student Learning Outcomes? Evidence from a New Experiment. JEL Category: A20, A22, I21, October 2004 